\title{
Article
}

\section{Improved Ductility of B Icosahedra-Based Superhard Materials Through Icosahedral Slip}

Qi An, and William A. Goddard

J. Phys. Chem. C, Just Accepted Manuscript • Publication Date (Web): 09 May 2017

Downloaded from http://pubs.acs.org on May 12, 2017

\section{Just Accepted}

"Just Accepted" manuscripts have been peer-reviewed and accepted for publication. They are posted online prior to technical editing, formatting for publication and author proofing. The American Chemical Society provides "Just Accepted" as a free service to the research community to expedite the dissemination of scientific material as soon as possible after acceptance. "Just Accepted" manuscripts appear in full in PDF format accompanied by an HTML abstract. "Just Accepted" manuscripts have been fully peer reviewed, but should not be considered the official version of record. They are accessible to all readers and citable by the Digital Object Identifier (DOI®). "Just Accepted" is an optional service offered to authors. Therefore, the "Just Accepted" Web site may not include all articles that will be published in the journal. After a manuscript is technically edited and formatted, it will be removed from the "Just Accepted" Web site and published as an ASAP article. Note that technical editing may introduce minor changes to the manuscript text and/or graphics which could affect content, and all legal disclaimers and ethical guidelines that apply to the journal pertain. ACS cannot be held responsible for errors or consequences arising from the use of information contained in these "Just Accepted" manuscripts. 


\title{
Improved Ductility of $B_{12}$ Icosahedra-based Superhard Materials through \\ Icosahedral Slip
}

\author{
Qi An, ${ }^{\dagger, *}$ and William A. Goddard III ${ }^{*}$ \\ ${ }^{\dagger}$ Department of Chemical and Materials Engineering, \\ University of Nevada, Reno, Reno, NV 89557, United States \\ ${ }^{\ddagger}$ Materials and Process Simulation Center, \\ California Institute of Technology, Pasadena, CA 91125, United States \\ *Corresponding author E-mail: qia@unr.edu
}

\begin{abstract}
Boron carbide $\left(\mathrm{B}_{4} \mathrm{C}\right)$ is superhard but suffers from brittle failure because shear stress leads to formation of amorphous shear bands in which the icosahedral clusters fracture, leading to amorphous regions with higher density than the crystal that results in tension induced cavitation and brittle failure. Based on our previous studies of related systems, we speculated that replacing the $\mathrm{C}-\mathrm{B}-\mathrm{C}$ chains with $\mathrm{Si}_{2}$ and replacing cage $\mathrm{C}$ with $\mathrm{Si}$ might reduce or eliminate this amorphous shear band formation responsible for brittle failure, In this paper we consider $\left(\mathrm{B}_{10} \mathrm{Si}_{2}\right) \mathrm{Si}_{2}$, using density functional theory (DFT) to examine its shear deformation. We find that the stress accumulated as shear increases is released by slip of the planes of icosahedra through breaking and then reforming the Si-Si chain bonds without fracturing $\left(\mathrm{B}_{10} \mathrm{Si}_{2}\right)$ icosahedra. This is because the $\left(\mathrm{B}_{10} \mathrm{Si}_{2}\right)$ icosahedra are more stable than the chain under highly stressed conditions. This chain disruption deformation mode prevents amorphous shear band formation, providing a strategy to dramatically improve the ductility of $\mathrm{B}_{4} \mathrm{C}$ based materials. Our results suggest that making the icosahedra more stable than the chains structure can lead to slipping of the icosahedral planes while avoiding the icosahedral fracturing that leads to brittle failure.
\end{abstract}




\section{Introduction}

Developing high strength and high ductility materials is of great interest for such applications as body armor vests, coatings in nuclear reactor, hypersonic vehicles, and cutting tools. ${ }^{1,2}$ Boron carbide $\left(\mathrm{B}_{4} \mathrm{C}\right)$ is one of the most promising candidate materials because of its superior properties of low density, high hardness, high thermal stability, and high elastic Hugoniot limit. ${ }^{1-5}$ However, extended engineering applications of $\mathrm{B}_{4} \mathrm{C}$ are limited by the brittle failure arising from the amorphous shear band formation under hypervelocity impact, ${ }^{6}$ indentation, ${ }^{7}$ laser shock, ${ }^{8}$ radiation, ${ }^{9}$ and mechanical scratching. ${ }^{10}$ Recently we carried out large-scale ReaxFF reactive molecule dynamics (RMD) simulations on the shear deformation of $\mathrm{B}_{4} \mathrm{C}$ for systems with cells lengths of $\sim 25 \mathrm{~nm}(\sim 200,000$ atom $)$, where we observed the formation of $\sim 3 \mathrm{~nm}$ wide amorphous shear bands for shear along both of the two plausible slip systems: $(0001) /<10 \overline{1} 0>$ and $(01 \overline{1} \overline{1}) /<\overline{1} 101>$. ${ }^{11}$ Analyzing the origin of the amorphous shear band formation we found that it arises because shear leads first to breaking C-B inter-cluster bonds that then react with the B of the C-B-C chains as the planes of icosahedral clusters are sheared. ${ }^{12}$ This leads to fracturing of the clusters, forming amorphous regions with an increased local density (because amorphous $\mathrm{B}_{4} \mathrm{C}$ is $5 \%$ more dense than crystalline $\mathrm{B}_{4} \mathrm{C}$ at $\left.50 \mathrm{GPa}\right) .{ }^{11}$ This leads to tension that causes cavitation and then crack opening. ${ }^{11}$ Thus to improve the ductility of $\mathrm{B}_{4} \mathrm{C}$ we must suppress the deconstruction of icosahedral clusters under highly compressed conditions. Here we propose two design strategies:

1. Replacing the 3-atom C-B-C chains with 2-atom chains to eliminate the highly reactive central atom. 
2. Making sure that the strength of the 2-atom chain is less than that of the icosahedron.

The stable structures of all these systems can be visualized as the closest packing of icosahedral clusters that are interconnected by each cluster bonding directly to 6 other clusters and to 6 chains. The terminal atom of each chain bonds to 3 different clusters. The lowest energy shear response is for one closest packed layer to shear with respect to the adjacent layer. To understand the mechanism we focus on the chains that bridge between the two plains being sheared. Each terminal atom of the chain has bonds to two icosahedra of one plane and to one cluster of the other plane along with the chain bond. To obtain ductile shear, we want each terminal atom to go from three bonds to clusters to four bonds and back to three without breaking any bonds within the cluster. That is the chain atoms log roll as the plane connect to them shear. This leads to the second criterion for ductile response.

Numerous studies have been made to improve the ductility of $\mathrm{B}_{4} \mathrm{C}$, both theory and experiments. ${ }^{15-21}$ Experimentally multiple phase materials $\mathrm{B}_{4} \mathrm{C}-\mathrm{B}_{6} \mathrm{O}$ and $\mathrm{B}_{4} \mathrm{C}-\mathrm{ZrB}_{2}$ have been synthesized to achieve improved fracture toughness. ${ }^{15,16}$ Indeed our previous QM calculations find that $\mathrm{B}_{4} \mathrm{C}-\mathrm{B}_{6} \mathrm{O}$ leads to improved ductility by suppressing the failure mechanism of $\mathrm{B}_{4} \mathrm{C} .{ }^{17}$ In addition, our DFT studies on boron suboxide $\left(\mathrm{B}_{6} \mathrm{O}\right)$, boron subphosphide $\left(\mathrm{B}_{12} \mathrm{P}_{2}\right)$, and $\left(\mathrm{B}_{11} \mathrm{C}_{\mathrm{p}}\right) \mathrm{Si}_{2}$ indicate that the icosahedral clusters do not deconstruct under pure shear deformation along the most favorable shear slip system. ${ }^{18,19}$ These results support our $1^{\text {st }}$ design strategy that replacing the C-B-C chains with 2-atom chains will increase the ductility. Subhash et al. demonstrated that filling the empty space in $\mathrm{B}_{4} \mathrm{C}$ using foreign atoms can also potentially prevent the structural 
collapse that leads to amorphization. ${ }^{20}$

Despite these extensive experimental and theoretical efforts, it has not been possible to achieve the high ductility in $\mathrm{B}_{4} \mathrm{C}$ related materials required for realistic engineering applications. Thus, we consider it essential to establish design principles for improved ductility under complex stress conditions. In particular, we want to establish our second design strategy of preventing deconstruction of icosahedral blocks under complex stress conditions (especially indentation) by ensuring that the chains are weaker than the bonds in the isosahedra. ${ }^{21}$

Consistent with our design factors we considered that $\left(\mathrm{B}_{10} \mathrm{Si}_{2}\right) \mathrm{Si}_{2}$ might prove to be ductile and if so it might be practical to synthesize it since only B and Si are involved. Consequently, we carried out DFT simulations to examine the stability, deformation modes, and other mechanical properties of two most stable $\left(\mathrm{B}_{10} \mathrm{Si}_{2}\right) \mathrm{Si}_{2}$ structures and compared their shear performance with $\mathrm{B}_{4} \mathrm{C}$.

\section{Methodology}

All simulations were performed using the plane wave projector augmented wave (PAW) method with the Perdew-Burke-Ernzerhof (PBE) functional as implemented in the Vienna Ab-initio Simulation Package (VASP) periodic code..$^{22-25}$ We used a plane-wave cutoff energy of $600 \mathrm{eV}$ which gives excellent convergence on energy, force, stress, and geometries. The energy error for terminating electronic self-consistent field (SCF) and the force criterion for the geometry optimization were set equal to $10^{-6} \mathrm{eV}$ and $10^{-3} \mathrm{eV} / \AA$, respectively. Brillouin-zone integration was performed on $\Gamma$-centered symmetry reduced Monkhorst-Pack meshes with a fine resolution of $2 \pi$ 
$\times 1 / 40 \AA^{-1}$ for all calculations except for the shear deformation. A more approximate $2 \times 2 \times 2$ mesh was used in the shear deformation.

To examine the stability of the $\left(\mathrm{B}_{10} \mathrm{Si}_{2}\right)$ icosahedron in the $\left(\mathrm{B}_{10} \mathrm{Si}_{2}\right) \mathrm{Si}_{2}$ crystal, we performed $a b$ initio molecular dynamics (AIMD) simulations on the $2 \times 2 \times 2$ supercell. The system was equilibrated at $300 \mathrm{~K}$ for 2 ps using the NVT ensemble (constant volume, constant temperature, and constant number of atoms). The energy criterion for convergence of the electronic self-consistent field (SCF) was set to $10^{-4} \mathrm{eV}$ and the force criterion for atom relaxation was set to $10^{-2} \mathrm{eV} / \AA$ in the AIMD simulations.

We first determine the elastic constant $C_{i j}$ from the stress-strain relationship as a function of various cell distortions from the equilibrium lattice configuration. ${ }^{26}$ Then, the stiffness constant $\mathrm{S}_{\mathrm{ij}}$ were derived from the matrix inversion of the elastic constant $C_{i j}$, which is $S_{i j}=\left(C_{i j}\right)^{-1}$. Finally, the Voigt-Reuss-Hill (VRH) approximation ${ }^{27}$ is applied to calculate the isotropic polycrystalline elastic moduli from the corresponding single-crystal elastic and stiffness constants.

To determine the ideal shear stress and the deformation mechanism under pure shear deformation, we imposed the strain for a particular shear plane while allowing full structure relaxation for the other five strain components. ${ }^{28}$ To mimic the complex stress conditions under indentation experiments, we applied biaxial shear deformation where the ratio of the compressive pressure beneath the indenter normal to the chosen shear plane has a fixed fraction of the tangential shear while the other four strain components are relaxed. ${ }^{29}$ The residual stresses after relaxing were less than $0.5 \mathrm{GPa}$ for both pure shear and biaxial shear deformation. 


\section{Results and Discussion}

The optimum distribution of atoms in $\mathrm{B}_{4} \mathrm{C}$ is predicted by $\mathrm{QM}$ to be $\left(\mathrm{B}_{11} \mathrm{C}_{\mathrm{p}}\right) \mathrm{CBC}$, ${ }^{11}$ leading to a rhombohedral unit cell with the $\left(\mathrm{B}_{11} \mathrm{C}_{\mathrm{p}}\right)$ icosahedron located at the corner and the C-B-C chain along the [111] rhombohedral direction. In $\left(\mathrm{B}_{11} \mathrm{C}_{\mathrm{p}}\right) \mathrm{CBC}$ one boron atom in the icosahedron is replaced by a carbon atom in the polar site that is bonded directly to a nearby icosahedron (not to the $\mathrm{C}-\mathrm{B}-\mathrm{C}$ chain). A second structure $\left(\mathrm{B}_{11} \mathrm{C}_{\mathrm{e}}\right) \mathrm{CBC}$ has the $\mathrm{C}$ in an equatorial site that connects to a C-B-C chain, leading to an energy $0.83 \mathrm{kcal} / \mathrm{mol}$ per atom higher. All bonds in the C-B-C chain and the extra-polyhedral bonds of the $\left(\mathrm{B}_{11} \mathrm{C}\right)$ unit can be considered as sigma bonds. Therefore, the middle $\mathrm{B}$ in the $\mathrm{C}-\mathrm{B}-\mathrm{C}$ chain is effectively $\mathrm{B}^{+}$, transferring one electron to an $\left(\mathrm{B}_{11} \mathrm{C}\right)$ icosahedron to satisfy Wade's rule (26 skeleton bonding electrons within the icosahedron). This suggests that we write $\mathrm{B}_{4} \mathrm{C}$ as $\left(\mathrm{B}_{11} \mathrm{C}\right)^{-1}-\left(\mathrm{C}-\mathrm{B}^{+}-\mathrm{C}\right)$. The reactivity of the central $\mathrm{B}^{+}$in $\mathrm{C}-\mathrm{B}-\mathrm{C}$ chain plays an important role in deconstructing the icosahedron during the shear process, leading to amorphous band formation. ${ }^{11,12}$

To modify this $\left(\mathrm{B}_{11} \mathrm{C}_{\mathrm{p}}\right) \mathrm{CBC}$ structure to achieve improved ductility, we first replaced the C-B-C chain with the 2-atom $\mathrm{Si}-\mathrm{Si}$ chain suggested by our previous studies, leading to $\left(\mathrm{B}_{11} \mathrm{C}_{\mathrm{p}}\right)(\mathrm{Si}-\mathrm{Si}){ }^{17,18}$ The overall structure is slightly compressed since the $\mathrm{Si}-\mathrm{Si}$ chain bond distance $(2.44 \AA)$ is shorter than the $\mathrm{C} \cdots \mathrm{C}$ bond distance $(2.87 \AA)$ in the C-B-C chain. Here each Si has makes bond to the other chain $\mathrm{Si}$ and three $\mathrm{Si}-\mathrm{B}$ bonds, one to each of three icosahedra. Replacing the C-B-C chain with $\mathrm{Si}_{2}$ chain, would lead to only 25 polyhedral electrons per $\left(\mathrm{B}_{11} \mathrm{Si}\right)$ icosahedron since it has 12 extra-icosahedral bonding with neighboring chains and icosahedra. To satisfy the Wade's rule, we substituted a $2^{\text {nd }}$ icosahedral $B$ atom with a Si atom leading to a 
composition that we denoted as $\left(\mathrm{B}_{10} \mathrm{Si}_{2}\right) \mathrm{Si}_{2}$. We find that this softens the icosahedron. In addition, the $\mathrm{Si}-\mathrm{Si}$ chain is more flexible than the $\mathrm{C}-\mathrm{B}-\mathrm{C}$ chain ${ }^{30}$, which allows extensive deformation under stress.

The distribution of $\mathrm{Si}$ atoms in the icosahedron leads to four possible crystalline structures shown in Fig. 1.

There are three forms of $\left(\mathrm{B}_{10} \mathrm{Si}_{2}\right) \mathrm{Si}_{2}$ in which there is one $\mathrm{Si}$ in the polar site of $\mathrm{B}_{4} \mathrm{C}$.

- $\quad$ ortho with the $\mathrm{Si}$ atoms adjacent $\left(\mathrm{o}-\mathrm{B}_{10} \mathrm{Si}_{2}\right) \mathrm{Si}_{2}$, Fig. 1(a). This is the most stable. For this distorted rhombohedral structure, PBE gives equilibrium lattice parameters $\mathrm{a}=5.705 \AA, \mathrm{b}=$ $5.705 \AA, \mathrm{c}=5.450 \AA$, and $\alpha=68.93^{\circ}, \beta=68.93^{\circ}, \gamma=68.59^{\circ}$, leading to a density of $2.46 \mathrm{~g} / \mathrm{cm}^{3}$. To test the stability of this structure we carried out 2 picoseconds of molecular dynamics (MD) on a unit cell 8 times bigger, using DFT derived forces (AIMD) at 298K. We found that no icosahedra deconstruct during the AIMD simulations at room temperature, as shown by the snapshot in the Fig. S1 of the Supporting Information (SI).

- $\quad$ meta with the $\mathrm{Si}$ atoms separate by one $\mathrm{B}$ atom $\left(\mathrm{m}-\mathrm{B}_{10} \mathrm{Si}_{2}\right) \mathrm{Si}_{2}$, Fig. $1(\mathrm{~b})$. This is the $2^{\text {nd }}$ most stable, only $0.10 \mathrm{eV} /$ unit-cell higher than ortho. For the distorted rhombohedral structure, PBE gives equilibrium lattice parameters $\mathrm{a}=5.706 \AA, \mathrm{b}=5.706 \AA, \mathrm{c}=5.452 \AA$, and $\alpha=68.77^{\circ}, \beta=$ $68.77^{\circ}, \gamma=68.43^{\circ}$, leading to a density of $2.47 \mathrm{~g} / \mathrm{cm}^{3}$.

- para with the $\mathrm{Si}$ atoms on opposite sides $\left(\mathrm{p}-\mathrm{B}_{10} \mathrm{Si}_{2}\right) \mathrm{Si}_{2}$, Fig. 1(c). This structure is 1.25 eV/unit-cell higher in energy than ortho because there are now Si-Si bonds between cages. For this distorted rhombohedral structure, PBE gives equilibrium lattice parameters a $=5.474 \AA, \mathrm{b}=$ 
$5.949 \AA, \mathrm{c}=5.474 \AA$, and $\alpha=68.81^{\circ}, \beta=69.18^{\circ}, \gamma=68.81^{\circ}$, leading to a density of $2.45 \mathrm{~g} / \mathrm{cm}^{3}$.

We will not consider this case further.

Previous QM studies on isomers $\left(\mathrm{B}_{10} \mathrm{Si}_{2}\right) \mathrm{H}_{12}$ found that $\left(\mathrm{p}-\mathrm{B}_{10} \mathrm{Si}_{2}\right) \mathrm{H}_{12}$ is more stable than (o- $\left.\mathrm{B}_{10} \mathrm{Si}_{2}\right) \mathrm{H}_{12}$ by $0.156 \mathrm{eV} ;{ }^{31}$ very close to the value of 0.100 we calculate. However, we find that the $\left(\mathrm{o}-\mathrm{B}_{10} \mathrm{Si}_{2}\right) \mathrm{Si}_{2}$ crystal is more stable than $\left(\mathrm{p}-\mathrm{B}_{10} \mathrm{Si}_{2}\right) \mathrm{Si}_{2}$ by $1.250 \mathrm{eV}$. Since the intra-icosahedral bonding should favor para, the stabilization much be related to inter-icosahedral bonds. To explain this, we calculated the energy of three clusters composed of two icosahedra (structures displayed in Fig. $\mathrm{S} 2$ of $\mathrm{SI}):\left(\mathrm{B}_{10} \mathrm{SiH}_{11}\right) \mathrm{Si}-\mathrm{Si}\left(\mathrm{B}_{10} \mathrm{SiH}_{11}\right), \quad\left(\mathrm{B}_{9} \mathrm{Si}_{2} \mathrm{H}_{11}\right) \mathrm{B}-\mathrm{B}\left(\mathrm{B}_{9} \mathrm{Si}_{2} \mathrm{H}_{11}\right)$, and $\left(\mathrm{B}_{10} \mathrm{SiH}_{11}\right) \mathrm{Si}-\mathrm{B}\left(\mathrm{B}_{9} \mathrm{Si}_{2} \mathrm{H}_{11}\right)$, leading to the results that $\left(\mathrm{B}_{10} \mathrm{SiH}_{11}\right) \mathrm{Si}-\mathrm{B}\left(\mathrm{B}_{9} \mathrm{Si}_{2} \mathrm{H}_{11}\right)$ is more stable than $\left(\mathrm{B}_{10} \mathrm{SiH}_{11}\right) \mathrm{Si}-\mathrm{Si}\left(\mathrm{B}_{10} \mathrm{SiH}_{11}\right)$ and $\left(\mathrm{B}_{9} \mathrm{Si}_{2} \mathrm{H}_{11}\right) \mathrm{B}-\mathrm{B}\left(\mathrm{B}_{9} \mathrm{Si}_{2} \mathrm{H}_{11}\right)$ by 0.090 and $0.377 \mathrm{eV}$, respectively. Considering there are four $\mathrm{Si}-\mathrm{B}$ intra-icosahedral bonds in $\left(\mathrm{o}-\mathrm{B}_{10} \mathrm{Si}_{2}\right) \mathrm{Si}_{2}$, the inter-icosahedral bonds provide an extra stabilization of $0.934 \mathrm{eV}$ for $\left(\mathrm{o}-\mathrm{B}_{10} \mathrm{Si}_{2}\right) \mathrm{Si}_{2}$ relative to $\left(\mathrm{p}-\mathrm{B}_{10} \mathrm{Si}_{2}\right) \mathrm{Si}_{2}$. This would suggest that $\left(\mathrm{o}-\mathrm{B}_{10} \mathrm{Si}_{2}\right) \mathrm{Si}_{2}$ should be $0.934 \mathrm{eV}$ more stable than $\left(\mathrm{p}-\mathrm{B}_{10} \mathrm{Si}_{2}\right) \mathrm{Si}_{2}$. In fact, we find that it is $1.250 \mathrm{eV}$ more stable. This extra energy difference arises from the fact that some intra-icosahedral bonds in $\left(\mathrm{p}-\mathrm{B}_{10} \mathrm{Si}_{2}\right) \mathrm{Si}_{2}$ are overly compressed, with an inter-icosahedral $\mathrm{Si}-\mathrm{Si}$ bond length is $2.22 \AA$ for the $\left(\mathrm{p}-\mathrm{B}_{10} \mathrm{Si}_{2}\right) \mathrm{Si}_{2}$ crystal, whereas the this bond distance is $2.31 \mathrm{~A}$ for the (p- $\left.\mathrm{B}_{10} \mathrm{Si}_{2}\right)-\left(\mathrm{p}-\mathrm{B}_{10} \mathrm{Si}_{2}\right)$ dimer (which is slightly smaller than the equilibrium Si-Si bond length in crystalline Silicon of $2.35 \AA$ and the Si-Si chain bonds of $2.44 \AA$ ).

In addition, we considered the structure in Fig. 1(d) in which one cage Si atom is located in the equatorial site. This structure is $0.71 \mathrm{eV} /$ unit-cell higher in energy than o- $\left(\mathrm{B}_{10} \mathrm{Si}_{2}\right) \mathrm{Si}_{2}$ because 
there are now $\mathrm{Si}-\mathrm{Si}$ bonds between the chain and the cluster. For this distorted rhombohedral structure, PBE gives equilibrium lattice parameters $\mathrm{a}=5.731 \AA, \mathrm{b}=5.472 \AA, \mathrm{c}=5.498 \AA$, and $\alpha$ $=70.83^{\circ}, \beta=69.14^{\circ}, \gamma=70.79^{\circ}$, leading to a density of $2.48 \mathrm{~g} / \mathrm{cm}^{3}$. We will not consider this structure further. Thus the cage Si atoms prefer to be located in polar sites.

In the following, we will focus on $\left(\mathrm{o}-\mathrm{B}_{10} \mathrm{Si}_{2}\right) \mathrm{Si}_{2}$ and $\left(\mathrm{m}-\mathrm{B}_{10} \mathrm{Si}_{2}\right) \mathrm{Si}_{2}$ because they are close in energy and much lower than the other two structures.

To examine how the structural changes affect the mechanical properties, we used QM to predict the elastic moduli of $\left(\mathrm{B}_{10} \mathrm{Si}_{2}\right) \mathrm{Si}_{2}$ which we compare with $\left(\mathrm{B}_{11} \mathrm{C}_{\mathrm{p}}\right) \mathrm{CBC}$. The bulk modulus (B) and shear modulus (G) are predicted using Voigt-Reuss-Hill averaging. ${ }^{29}$ The results are in Table S1 of the SI. We find

- $\mathrm{B}=160.1 \mathrm{GPa}$ and $\mathrm{G}=136.6 \mathrm{GPa}$ for ortho,

- $\quad \mathrm{B}=159.7 \mathrm{GPa}$ and $\mathrm{G}=138.3 \mathrm{GPa}$ for meta, and

- $\mathrm{B}=238.0 \mathrm{GPa}$ and $\mathrm{G}=199.0 \mathrm{GPa}$ for $\left(\mathrm{B}_{11} \mathrm{C}_{\mathrm{p}}\right) \mathrm{CBC},{ }^{11}$ which is $48.7 \%$ and $45.7 \%$ higher than $\mathrm{B}$ and $\mathrm{G}$ for $\left(\mathrm{o}-\mathrm{B}_{10} \mathrm{Si}_{2}\right) \mathrm{Si}_{2}$, respectively.

Generally, the materials strength is judged by indentation hardness, which measures the resistance of materials to deformation at a constant compression load. Our calculated Vickers hardness $\left(H_{v}\right)$ for polycrystalline materials based on $G / B^{32}$ leads to (Table $S 1$ ).

- $\mathrm{H}_{\mathrm{v}}=26.5 \mathrm{GPa}$ for o- $\left(\mathrm{B}_{10} \mathrm{Si}_{2}\right) \mathrm{Si}_{2}$,

- $\mathrm{H}_{\mathrm{v}}=27.2 \mathrm{GPa}$ for $\mathrm{m}-\left(\mathrm{B}_{10} \mathrm{Si}_{2}\right) \mathrm{Si}_{2}$, and 
- $\mathrm{H}_{\mathrm{v}}=32.9 \mathrm{GPa}$ for $\left(\mathrm{B}_{11} \mathrm{C}_{\mathrm{p}}\right) \mathrm{CBC}$.

We also calculated the Knoop hardness based on the electronegativities and covalent radii of the constituent atoms, and the bond lengths in the structure. ${ }^{33}$ This leads to $H=23.5,27.7$ and 34.3 GPa for $\left(\mathrm{o}-\mathrm{B}_{10} \mathrm{Si}_{2}\right) \mathrm{Si}_{2},\left(\mathrm{~m}-\mathrm{B}_{10} \mathrm{Si}_{2}\right) \mathrm{Si}_{2}$, and $\left(\mathrm{B}_{11} \mathrm{C}_{\mathrm{p}}\right) \mathrm{CBC}$, respectively. This agrees very well with the above predicted Vickers hardness based on G/B. Thus, $\left(0-\mathrm{B}_{10} \mathrm{Si}_{2}\right) \mathrm{Si}_{2}$ and $\left(\mathrm{m}-\mathrm{B}_{10} \mathrm{Si}_{2}\right) \mathrm{Si}_{2}$ are $19.5 \%$ and $17.3 \%$ lower in Vickers hardness compared to $\left(B_{11} C_{p}\right) C B C$, respectively, indicating they are a bit softer than $\mathrm{B}_{4} \mathrm{C}$. However, their hardness is still comparable to the extremely hard ceramics $\mathrm{ZrC}$, TiC and TiN which have $\mathrm{H}_{\mathrm{v}}$ of 25.2 28.8 using the same G/B approach. ${ }^{32}$

To examine how the modified structure affects the deformation mechanism, we first applied pure shear deformation to the ground state structure $\left(\mathrm{o}-\mathrm{B}_{10} \mathrm{Si}_{2}\right) \mathrm{Si}_{2}$. Previous shear deformation on $\mathrm{B}_{4} \mathrm{C}$ showed that $\{001\} /[100]$ slip system is the most favorable among 11 possible slip systems. ${ }^{12}$ Since the $\left(\mathrm{B}_{10} \mathrm{Si}_{2}\right) \mathrm{Si}_{2}$ is the modified from $\mathrm{B}_{4} \mathrm{C}$, we chose the most favorable stress shear slip system to be $\{001\} /[100]$. Here we use the 3-index to represent the planes and directions in rhombohedral cell.

Our studies of the shear deformation of $\mathrm{B}_{4} \mathrm{C}$ found that the first step in the "plastic" deformation was to break a boron-carbon bond between neighboring icosahedral clusters. ${ }^{12}$ For o-( $\left(\mathrm{B}_{10} \mathrm{Si}_{2}\right) \mathrm{Si}_{2}$ we considered three possible slip systems belonging to $\{001\} /[100]$ slip system (displayed in Fig. S3 of SI):

(1) the $(010) /<001>$ where the silicon-boron bond between neighboring icosahedra is stretched under shear deformation; 
(2) the $(001) /<100>$ where the boron-boron bond between neighboring icosahedra is stretched under shear deformation;

(3) the $(100) /<010>$, oriented such that the silicon-boron bond between neighboring icosahedra is stretched under shear deformation.

The shear-stress-shear-strain relationships displayed in Fig. 2(a) show that the barrier stress for ideal shear deformation along $(010) /<001>$ is $26.3 \mathrm{GPa}$, which is $7.7 \%$ lower than that for shearing along $(001) /<100>(28.5 \mathrm{GPa})$ and $2.2 \%$ lower than for shearing along $(100) /<010>$ (26.9 GPa). Therefore, $(010) /<001>$ is the least stress shear slip system for o- $\left(\mathrm{B}_{10} \mathrm{Si}_{2}\right) \mathrm{Si}_{2}$.

The details of the deformation and failure process for shearing along $(010) /<001>$ are displayed in Fig. 2(b)-(d). Fig. 2(b) displays the intact structure before shear. As the system is sheared to 0.322 strain before failure (Fig. 2(c)), the Si31-B38 bond between neighboring icosahedra does not break, with the bond length increasing only from 1.98 to $2.17 \AA$, but the Si31-B22 bond within the icosahedron breaks with a bond length increase from 2.10 to $2.65 \AA$. This broken bond within the icosahedron leads to deconstruction of the clusters as the strain increases to 0.345 , as shown in Fig. 2(d). This failure process indicates that the $\left(B_{10} S i_{2}\right)$ icosahedron in o-( $\left(B_{10} \mathrm{Si}_{2}\right) \mathrm{Si}_{2}$ is less stable than Si-Si chain structure under shear deformation. This failure mode is different from the failure mode of $\mathrm{B}_{4} \mathrm{C}$ where the $\mathrm{C}-\mathrm{B}-\mathrm{C}$ chain reacts with the carbene formed by breaking the boron-carbon bond between neighboring icosahedral clusters. ${ }^{12}$ However, we expect that the icosahedra deconstruction will lead to amorphous band formation in o- $\left(\mathrm{B}_{10} \mathrm{Si}_{2}\right) \mathrm{Si}_{2}$, similar to that $\mathrm{B}_{4} \mathrm{C}$. Thus, o- $\left(B_{10} S i_{2}\right) S i_{2}$ should be brittle. Here the 
critical stress for failure is predicted to be $26.3 \mathrm{GPa}$, which is $32.5 \%$ lower than for $\left(\mathrm{B}_{11} \mathrm{C}_{\mathrm{p}}\right) \mathrm{CBC}$.

Then we examined the shear deformation $\mathrm{m}-\left(\mathrm{B}_{10} \mathrm{Si}_{2}\right) \mathrm{Si} 2$, which is $0.10 \mathrm{eV}$ per formula unit less stable. Here we also examined three possible slip systems belonging to $\{001\} /[100]$ : $(100) /<001>,(010) /<100>$, and $(010) /<001>$. The stress-strain relationship in Fig. 3(a) indicates that the ideal shear stress along $(010) /<100>$ is $27.5 \mathrm{GPa}$ which is less than that of shearing along $(100) /<001>(28.6 \mathrm{GPa})$ and $(010) /<001>(28.6 \mathrm{GPa})$. Thus, $(010) /<100>$ is the least stress shear slip system for m-( $\left.\mathrm{B}_{10} \mathrm{Si}_{2}\right) \mathrm{Si}_{2}$.

The detailed deformation mode and failure of $\mathrm{m}-\left(\mathrm{B}_{10} \mathrm{Si}_{2}\right) \mathrm{Si}_{2}$ shearing along $(010) /<100>$ is displayed in Fig. 3(b)-(f).

1. 0 to 0.276 strain: The system deforms elastically until 0.144 shear strain and reaches a maximum shear stress at 0.276 strain. No bonds broken as shown in Fig. 3(b). The most stretched bond is the Si1-B1 bond from the cage to the chain, which increases from 1.98 to $2.39 \AA$.

2. 0.276 to 0.322 strain: As the shear strain increases, the Si-Si chain bond increases from 2.43 to $2.64 \AA$ while the Si1-B1 bond from the cage to the chain increases to $2.57 \AA$, without fracturing the $\left(\mathrm{B}_{10} \mathrm{Si}_{2}\right)$ icosahedra, as shown in Fig. 3(c).

3. 0.322 to 0.345 strain: The Si1-B1 and Si-Si chain bonds both break, leading to the formation of new Si2-B1 bond shown in Fig. S1(d). This process releases the shear stress from 25.9 GPa to 6.5 GPa. However, no icosahedra are disintegrated in this process, as shown in Fig. 3(d).

4. 0.345 to 0.628 strain: As the shear strain further increases continuously, the shear stress 
monotonically increases to $19.5 \mathrm{GPa}$ without destroying the $\left(\mathbf{B}_{\mathbf{1 0}} \mathbf{S i} \mathbf{i}_{2}\right)$ icosahedra as shown in Fig. 3(e).

5. Above 0.628 . We observe critical failure strain, with one layer of $\left(\mathrm{B}_{10} \mathrm{Si}_{2}\right)$ icosahedra deconstructing (Fig. 3(f)), leading to structural failure.

We also examined the deformation processes of $\mathrm{m}-\left(\mathrm{B}_{10} \mathrm{Si}_{2}\right) \mathrm{Si}_{2}$ shearing along $(010) /<001>$ and $(100) /<001>$ even though the stress barrier is $1.1 \mathrm{GPa}$ higher than the least stress shear slip system $(010) /<100>$. As the intact structure (Fig. 4(a)) is sheared along (010)/ $<001>$ slip system, the Si-Si chain bond and icosahedral B-B bond are stretched from 2.42 and $1.76 \AA$ to 2.55 and $2.34 \AA$, respectively, at 0.299 strain. But they are not broken, as shown in Fig. 4 (b). These two bonds are both broken at 0.369 strain and the chain $\mathrm{Si}$ is bonded to the icosahedral $\mathrm{B}$, as shown in Fig. 4(c). This process releases the shear stress without deconstructing the icosahedra, leading to the $1^{\text {st }}$ shear stress drop. As the shear strain is continuously increased to 0.805 strain, the Si-Si chain bond is reformed and the structure recovers as shown in Fig. 4(d)! This structure recovery is similar to previous observations in $\mathrm{B}_{6} \mathrm{O}^{17}$ and $\left(\mathrm{B}_{11} \mathrm{C}\right) \mathrm{Si}_{2}{ }^{18}$.

For the $(100) /<001>$ slip system, the icosahedra deconstruct at the first stress decrease, as shown in Fig. S4 of SI. This suggests that amorphous shear bands might form if the $(100) /<001>$ slip system is activated. However, this might be rare under realistic conditions since the stress barrier of this slip system is $1.1 \mathrm{GPa}$ higher than for $(010) /<100>$.

This failure process along the most plausible slip system indicates that the $\left(\mathrm{B}_{10} \mathrm{Si}_{2}\right)$ icosahedra in $\mathrm{m}-\left(\mathrm{B}_{10} \mathrm{Si}_{2}\right) \mathrm{Si}_{2}$ are more stable than the $\mathrm{Si}-\mathrm{Si}$ chain structure allowing the stress to 
be released by breaking the $\mathrm{Si}-\mathrm{Si}$ chain bond. This suggests that $\mathrm{m}-\left(\mathrm{B}_{10} \mathrm{Si}_{2}\right) \mathrm{Si}_{2}$ is much more ductile than o- $\left(\mathrm{B}_{10} \mathrm{Si}_{2}\right) \mathrm{Si}_{2}$.

Realistic conditions lead to very complicated stress condition. Our previous study indicated that the icosahedra in $\mathrm{B}_{6} \mathrm{O}$ can fracture for biaxial shear deformation but not under pure shear deformation. ${ }^{21}$ Thus, it is essential to examine the deformation of $\mathrm{m}-\left(\mathrm{B}_{10} \mathrm{Si}_{2}\right) \mathrm{Si}_{2}$ structure under complex stress conditions. Here we examined the shear deformation under biaxial shear deformations that mimic the indentation experiments and compare to $\left(\mathrm{B}_{11} \mathrm{C}_{\mathrm{p}}\right) \mathrm{CBC} .^{21}$ Fig. 5(a) displays the shear-stress-shear-strain relationship for $\mathrm{m}-\left(\mathrm{B}_{10} \mathrm{Si}_{2}\right) \mathrm{Si}_{2}$ and $\left(\mathrm{B}_{11} \mathrm{C}_{\mathrm{p}}\right) \mathrm{CBC}$. The critical shear stress for $\mathrm{m}-\left(\mathrm{B}_{10} \mathrm{Si}_{2}\right) \mathrm{Si}_{2}$ is $16.7 \mathrm{GPa}$, which is much less than the value of $28.5 \mathrm{GPa}^{21}$ for $\left(\mathrm{B}_{11} \mathrm{C}_{\mathrm{p}}\right) \mathrm{CBC}$. Again, the shear stress for $\left(\mathrm{B}_{10} \mathrm{Si}_{2}\right) \mathrm{Si}_{2}$ increases continuously after the first significant drop at 0.231 strain. Then it dramatically drops the second time at 0.339 strain. This suggests that the deformation mechanism for $\left(\mathrm{B}_{10} \mathrm{Si}_{2}\right) \mathrm{Si}_{2}$ under biaxial shear deformation is different from $\left(\mathrm{B}_{11} \mathrm{C}_{\mathrm{p}}\right) \mathrm{CBC}$.

The detailed deformation process of $\left(\mathrm{B}_{10} \mathrm{Si}_{2}\right) \mathrm{Si}_{2}$ under biaxial shear deformation is displayed in Fig. 5(b)-(f). As the strain increases to 0.187 , corresponding to the maximum shear stress of 16.7 GPa, no bonds break as shown in Fig. 5(b). The B1-Si1 bond from the cluster to the chain decreases from the original value of 1.98 to $1.88 \AA$ due to the compressive normal stress. As the shear strain increases to 0.209 (before the first stress drop), there is still no bond broken, as displayed in Fig. 5(c). The Si2-Si4 chain bond decreases slightly from the original 2.43 to $2.41 \AA$. However, the $\left(\mathrm{B}_{10} \mathrm{Si}_{2}\right)$ icosahedra move close to the $\mathrm{Si}-\mathrm{Si}$ chain. The interaction of the icosahedra 
and the Si-Si chain under compressive stress leads to breaking the Si2-Si4 chain bond after a critical strain of 0.231 . This forms stacking faults of icosahedra as shown in Fig. 5(d), leading to a release of the shear stress from 15.3 to $4.3 \mathrm{GPa}$. However, no $\left(\mathbf{B}_{10} \mathbf{S i}_{2}\right)$ icosahedra are deconstructed. In contrast, the icosahedra in $\mathrm{B}_{4} \mathrm{C}$ and $\mathrm{B}_{6} \mathrm{O}$ both deconstruct under biaxial shear deformation due to the interaction between the icosahedra and chains. ${ }^{21}$ As the shear strain increases further to 0.319 strain (before the $2^{\text {nd }}$ stress release), no icosahedra disintegrate, as shown in Fig. 5(e). After passing the second critical strain, one layer of icosahedra deconstructs at 0.339 strain, as displayed in Fig. 5(f). This leads to the fracture failure of $\left(\mathrm{B}_{10} \mathrm{Si}_{2}\right) \mathrm{Si}_{2}$.

The deformation mode of $\mathrm{m}-\left(\mathrm{B}_{10} \mathrm{Si}_{2}\right) \mathrm{Si}_{2}$ suggests that the accumulated stress can be released by icosahedral slipping to form stacking faults without fracturing icosahedra. This icosahedral slip leads to formation of stacking faults, which suggests that mobile dislocations might be formed for $\left(\mathrm{B}_{10} \mathrm{Si}_{2}\right)$, which might provide an important mechanism to improve the ductility.

The main failure mechanism of $\mathrm{B}_{4} \mathrm{C}$ is amorphous shear band formation rather than forming mobile dislocations in $\mathrm{B}_{4} \mathrm{C} .{ }^{34}$ However, modifying $\mathrm{B}_{4} \mathrm{C}$ to $\mathrm{m}-\left(\mathrm{B}_{10} \mathrm{Si}_{2}\right) \mathrm{Si}_{2}$ we now activate an alternative deformation model of icosahedral slip. We note here that this icosahedral slip deformation mode might be suppressed under other loading conditions such as uniaxial compression or tension.

To improve the ductility of the $\mathrm{B}_{4} \mathrm{C}$ based materials, it is essential to prevent icosahedra disintegration under highly compressed states. The icosahedra in $\mathrm{B}_{4} \mathrm{C}, \mathrm{B}_{6} \mathrm{O}$ and o- $\left(\mathrm{B}_{10} \mathrm{Si}_{2}\right) \mathrm{Si}_{2}$ all deconstruct under biaxial shear deformation, but they do not disintegrate for $\mathbf{m}-\left(\mathbf{B}_{\mathbf{1 0}} \mathbf{S i}_{\mathbf{2}}\right) \mathbf{S i}_{\mathbf{2}}$. 
This suggests that merely replacing the C-B-C chain with 2-atom chain is not sufficient to guaranteed improved ductility under complex stress conditions. We must also make the icosahedron stronger than the chain bond so that the stress can be released by breaking the chain to activate the icosahedral slip.

Although $\mathrm{m}-\left(\mathrm{B}_{10} \mathrm{Si}_{2}\right) \mathrm{Si}_{2}$ is more ductile, it is very slightly less stable than o- $\left(\mathrm{B}_{10} \mathrm{Si}_{2}\right) \mathrm{Si}_{2}$. Given this small difference, we expect that synthesizing pure $\left(\mathrm{B}_{10} \mathrm{Si}_{2}\right) \mathrm{Si}_{2}$ would likely include a mixture of the meta and ortho structures with nearly $50 \%$ of each. Our results also suggest that activating icosahedral slip can be achieved by decreasing the chain strength to make it weaker than the icosahedron.

\section{Summary}

Summarizing, we examined the shear deformation of $\left(\mathrm{B}_{10} \mathrm{Si}_{2}\right) \mathrm{Si}_{2}$ to illustrate the design principles for improved ductility of $\mathrm{B}_{4} \mathrm{C}$ related materials. The m-( $\left(\mathrm{B}_{10} \mathrm{Si}_{2}\right) \mathrm{Si}_{2}$ structure displays an alternative deformation mode of icosahedral slip, in contrast to $\left(\mathrm{B}_{11} \mathrm{C}_{\mathrm{p}}\right) \mathrm{CBC}$. Under pure shear and indentation stress conditions, this mode releases the stress through slipping layered icosahedra rather than forming an amorphous shear band. Our results suggest that formatting stacking faults by icosahedral slip in $\mathrm{m}-\left(\mathrm{B}_{10} \mathrm{Si}_{2}\right) \mathrm{Si}_{2}$ is likely a major deformation mechanism, which suppresses the amorphous shear band formation and improves the ductility.

Summarizing to design $\mathrm{B}_{4} \mathrm{C}$ like ductile superhard materials we should include two factors:

(1) Replacing C-B-C chain with 2-atom chain; and

(2) decreasing the chain strength to activate the icosahedral slipped under complex stress 16 
conditions.

\section{ASSOCIATED CONTENT \\ Supporting Information}

The Supporting Information (SI) is available free of charge on the ACS Publications website. The SI includes the tables including the predicted bulk modulus, shear modulus, hardness and ideal shear stress for o- $\left(\mathrm{B}_{10} \mathrm{Si}_{2}\right) \mathrm{Si}_{2}, \mathrm{~m}-\left(\mathrm{B}_{10} \mathrm{Si}_{2}\right) \mathrm{Si}_{2}$ and $\left(\mathrm{B}_{11} \mathrm{C}_{\mathrm{p}}\right) \mathrm{CBC}$, the predicted elastic constant for o- $\left(\mathrm{B}_{10} \mathrm{Si}_{2}\right) \mathrm{Si}_{2}$ and $\mathrm{m}-\left(\mathrm{B}_{10} \mathrm{Si}_{2}\right) \mathrm{Si}_{2}$. The SI also includes the figures including the final snapshot of (o- $\left.\mathrm{B}_{10} \mathrm{Si}_{2}\right) \mathrm{Si}_{2}$ in AIMD simulations at $300 \mathrm{~K}$; Plausible slip systems for (o- $\left.\mathrm{B}_{10} \mathrm{Si}_{2}\right) \mathrm{Si}_{2}$ belonging to $\{001\} /[100]$ slip system; The structural changes for $\left(m-\mathrm{B}_{10} \mathrm{Si}_{2}\right) \mathrm{Si}_{2}$ shearing along $(100) /<001>$ slip system.

\section{Acknowledgements}

This work was initiated with support by the Defense Advanced Research Projects Agency (W31P4Q-13-1-0010 and W31P4Q1210008, program manager, John Paschkewitz) It was completed with support by the National Science Foundation (DMR-1436985, program manager, John Schlueter). Q.A. was also supported by the Army Research Laboratory under Cooperative Agreement Number W911NF-12-2-0022 and by the U. S. Nuclear Regulatory Commission (NRC-HQ-84-15-G-0028).

\section{Additional information}

The authors declare no competing financial interests. 


\section{REFERENCES}

(1) Thevenot, F. Boron Carbide-A Comprehensive Review. J. Eur. Ceram. Soc. 1990, 6, 205-225.

(2) Domnich, V.; Reynaud, S.; Haber, R. A.; Chhowalla, M. Boron Carbide: Structure, Properties, and Stability under Stress. J. Am. Ceram. Soc. 2011, 94, 3605-3628.

(3) The Chemistry of Boron and Its Compounds; Muetterties, E. L., Eds.; Wiley: New York, 1967.

(4) Suri, A. K.; Subramanian, C.; Sonber, J. K.; Murthy, T. Synthesis and Consolidation of Boron Carbide: A Review. Int. Mater. Rev. 2010, 55, 4-40.

(5) Bourne, N. K. Shock-induced Brittle Failure of Boron Carbide. Proc. R. Soc. London, Ser. A 2002, 458, 1999-2006.

(6) Chen, M. W.; McCauley, J. W.; Hemker, K. J. Shock-Induced Localized Amorphization in Boron Carbide. Science 2003, 299, 1563-1566.

(7) Reddy, K. M.; Liu, P.; Hirata, A.; Fujita, T.; Chen, M. W. Atomic Structure of Amorphous Shear Bands in Boron Carbide. Nat. Commun. 2013, 4, 2483.

(8) Zhao, S. T.; Kada, B.; Remington, B. A.; LaSalviac, J. C.; Wehrenberg, C. E.; Behlerc, K. D.; Meyers, M. A. Directional Amorphization of Boron Carbide Subjected to Laser Shock Compression. Proc. Natl. Acad. Sci. U.S.A. 2016, 113, 12088-12093.

(9) Gosset, D.; Miro, S.; Doriot, S.; Victor, G.; Motte, V. Evidence of Amorphisation of B ${ }_{4} C$ 
Boron Carbide under Slow, Heavy Ion Irradiation. Nucl. Instrum. Methods Phys. Res., Sect. B 2015, 365, 300-304.

(10) Chen, M. W.; McCauley, J. W. Mechanical Scratching Induced Phase Transitions and Reactions of Boron Carbide. J. Appl. Phys. 2006, 100, 123517.

(11) An, Q.; Goddard, W. A. III. Atomistic Origin of Brittle Failure of Boron Carbide from Large-Scale Reactive Dynamics Simulations: Suggestions toward Improved Ductility. Phys. Rev. Lett. 115, 2015, 105501.

(12) An, Q.; Goddard, W. A. III; Cheng, T. Atomistic Explanation of Shear-Induced Amorphous Band Formation in Boron Carbide. Phys. Rev. Lett. 2014, 113, 095501.

(13) Fanchini, G.; McCauley, J. W.; Chhowalla, M. Behavior of Disordered Boron Carbide under Stress. Phys. Rev. Lett. 2006, 97, 035502.

(14) Yan, X. Q.; Tang, Z.; Zhang, L.; Guo, J. J.; Jin, C. Q.; Zhang, Y.; Goto, T.; McCauley, J. W.; Chen, M. W. Depressurization Amorphization of Single-Crystal Boron Carbide. Phys. Rev. Lett. 2009, 102, 075505.

(15) Chen, C.; He, D. W.; Kou, Z.; Peng, F.; Yao, L.; Yu, R.; Bi, Y. B 6 O-Based Composite to Rival Polycrystalline Cubic Boron Nitride. Adv. Mater. 2007, 19, $4288-4291$.

(16) Nikzad, L.; Orru, R.; Licheri, R.; Cao, G. Fabrication and Formation Mechanism of $\mathrm{B}_{4} \mathrm{C}-\mathrm{TiB}_{2}$ Composite by Reactive Spark Plasma Sintering Using Unmilled and 
Mechanically Activated Reactants. J. Am. Ceram. Soc. 2012, 95, 3463-3471.

An, Q.; Goddard, W. A. III. Boron Suboxide and Boron Subphosphide Crystals:

Hard Ceramics That Shear without Brittle Failure. Chem. Mater. 2015, 27, 2855-2860.

An, Q.; Goddard, W. A. III. Microalloying Boron Carbide with Silicon to Achieve Dramatically Improved Ductility. J. Phys. Chem. Lett. 2014, 5, 4169-4174.

(19) Tang, B.; An, Q.; Goddard, W. A. III. Improved Ductility of Boron Carbide by Microalloying with Boron Suboxide. J. Phys. Chem. C 2015, 119, 24649-24656.

(20) Subhash, G.; Awasthi, A. P.; Kunka, C.; Jannotti, P.; DeVries, M. In Search of Amorphization-Resistant Boron Carbide. Scr. Mater. 2016, 123, 158-162.

(21) An, Q.; Reddy, K. M.; Qian, J.; Hemker, K. J.; Chen, M. W.; Goddard, W. A. III. Nucleation of Amorphous Shear Bands at Nanotwins in Boron Suboxide. Nat. Comm. 2016, 7, 11001 .

(22) Kresse, G.; Hafner, J. Ab Initio Molecular Dynamics for Liquid Metals. Phys. Rev. $B$ 1993, 47, 558-561.

(23) Kresse, G.; Furthmuller, J. Efficiency of Ab-Initio Total Energy Calculations for Metals and Semiconductors Using a Plane-Wave Basis Set. Comput. Mater. Sci. 1996, 6, $15-50$.

(24) Kresse, G.; Furthmüller, J. Efficient Iterative Schemes for Ab Initio Total-Energy Calculations Using a Plane-Wave Basis Set. Phys. Rev. B 1996, 16, 11169-11186. 
(25) Kresse, G.; Joubert, D. From Ultrasoft Pseudopotentials to the Projector Augmented-Wave Method. Phys. Rev. B 1999, 59, 1758-1775.

(26) Le Page, Y.; Saxe, P. Symmetry-General Least-Squares Extraction of Elastic Data for Strained Materials from Ab Initio Calculations of Stress. Phys. Rev. B 2002, 65, 104104.

(27) Hill, R. The Elastic Behaviour of a Crystalline Aggregate. Proc. Phys. Soc. A 1952, $65,349-354$.

(28) Roundy, D.; Krenn, C. R.; Cohen, M. L.; Morris, J. W. Jr. Ideal Shear Strengths of fcc Aluminum and Copper. Phys. Rev. Lett. 1999, 82, 2713-2716.

(29) Li, B.; Sun, H.; Chen, C. F. Large Indentation Strain-Stiffening in Nanotwinned Cubic Boron Nitride. Nat. Commun. 2014, 5, 4965.

(30) Jemmis, E. D.; Prasas, B. V.; Tsuzuki, S.; Tanabe, K. Analogy between Trivalent Boron and Divalent Silicon. J. Phys. Chem. 1990, 94, 5530-5535.

(31) Jemmis, E. D.; Kiran, B.; Coffery, D. Jr. Ab Initio Studies on Disubstituted closo-Icosahedral Heteroboranes, $\mathrm{X}_{2} \mathrm{~B}_{10} \mathrm{H}_{12}(\mathrm{X}=\mathrm{CH}$, SiH, N, P, and Sb). Chem. Ber. 1997, 130, 1147-1150.

(32) Chen, X. Q.; Niu, H. Y.; Li, D. Z.; Li, Y. Y. Modeling Hardness of Polycrystalline Materials and Bulk Metallic Glasses. Intermetallics 2011, 19, 1275-1281.

(33) Lyakhov, A. O.; Oganov, A. R. Evolutionary Search for Superhard Materials: 
Methodology and Applications to Forms of Carbon and $\mathrm{TiO}_{2}$. Phys. Rev. B 2011, 84, 092103.

(34) Farbaniec, L.; Hogan, J. D.; Xie, K. Y.; Shaeffer, M.; Hemker, K. J.; Ramesh, K. T. Damage Evolution of Hot-Pressed Boron Carbide under Confined Dynamic Compression, Int. J. Impact Eng. 2017, 99, 75-84. 


\section{Figure 1}
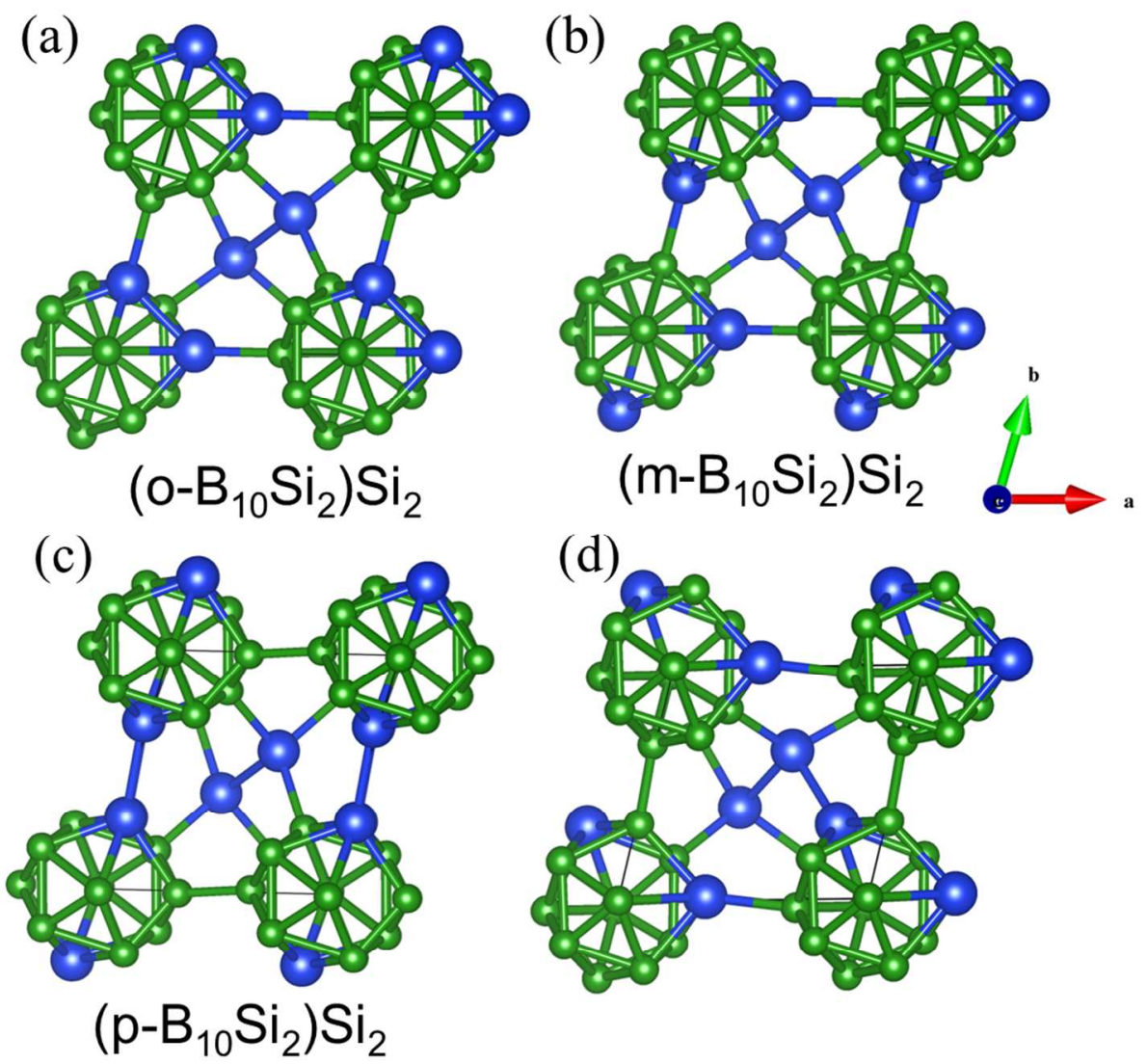

Figure 1. Stable structures with chemical formula $\left(\mathrm{B}_{10} \mathrm{Si}_{2}\right) \mathrm{Si}_{2}$ : (a) (Ortho- $\left.\mathrm{B}_{10} \mathrm{Si}_{2}\right) \mathrm{Si}_{2}$ which is the lowest energy structure; (b) (Meta- $\left.\mathrm{B}_{10} \mathrm{Si}_{2}\right) \mathrm{Si}_{2}$ which is only $0.10 \mathrm{eV} /$ unit-cell higher in energy than (o- $\left.\mathrm{B}_{10} \mathrm{Si}_{2}\right) \mathrm{Si}_{2}$; (c) (Para- $\left.\mathrm{B}_{10} \mathrm{Si}_{2}\right) \mathrm{Si}_{2}$ where the $\mathrm{Si}-\mathrm{Si}$ cage-cage bonds leads to an energy that is $1.25 \mathrm{eV} /$ unit-cell higher in energy than $\left(\mathrm{o}-\mathrm{B}_{10} \mathrm{Si}_{2}\right) \mathrm{Si}_{2}$; (d) Structure in which one cage $\mathrm{Si}$ is located in an equatorial site and bonded to chain Si. Here the cage Si to chain Si bonds lead to an energy that is $0.71 \mathrm{eV} /$ unit-cell higher in energy than $\left(\mathrm{o}-\mathrm{B}_{10} \mathrm{Si}_{2}\right) \mathrm{Si}_{2}$. The $\mathrm{B}$ and $\mathrm{Si}$ atoms are represented by green and blue balls, respectively. 
Figure 2
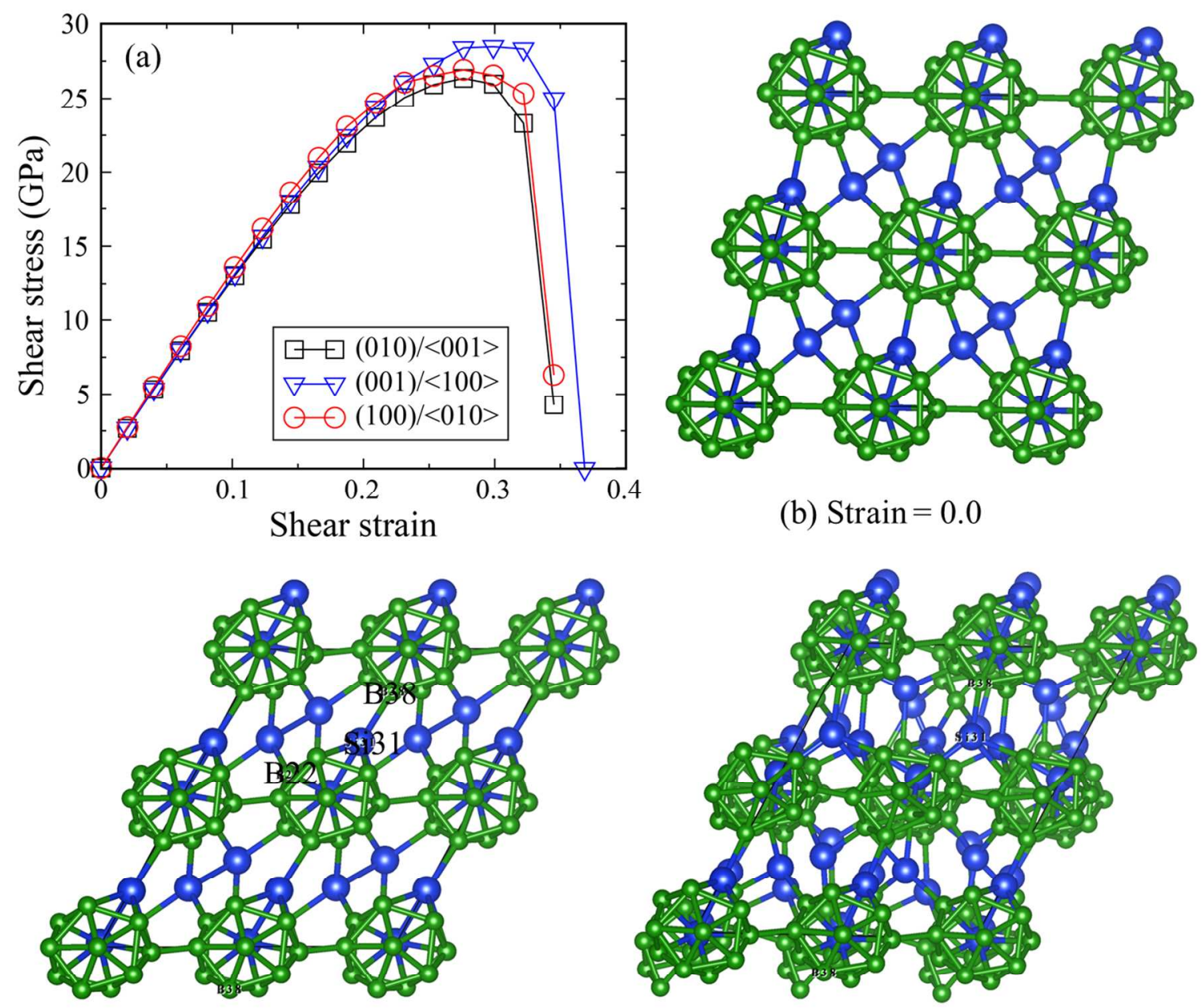

(c) Strain $=0.322$

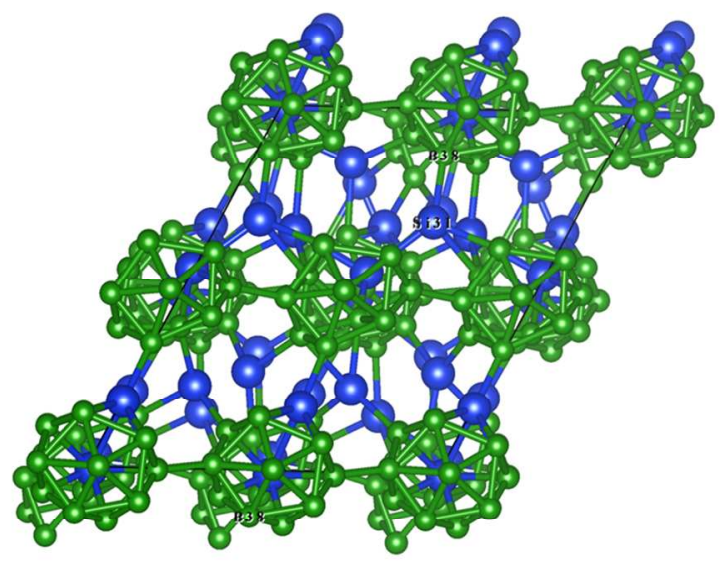

(d) Strain $=0.345$

Figure 2. The shear-stress-shear-strain relationship and structural changes for $\left(0-\mathrm{B}_{10} \mathrm{Si}_{2}\right) \mathrm{Si}_{2}$ shearing along the least shear slip system of $(010) /<001>$ : (a) shear-stress - shear-strain relationships along two slip systems; (b) intact structure prepared to shear along $(001) /<001>$; (c) structure at 0.322 strain before structure failure; (d) structure at 0.345 strain after structure failure; this shows deconstructed $\left(\mathrm{B}_{10} \mathrm{Si}_{2}\right)$ cages. The $\mathrm{B}$ and $\mathrm{Si}$ atoms are represented by green and blue balls, respectively. 
Figure 3

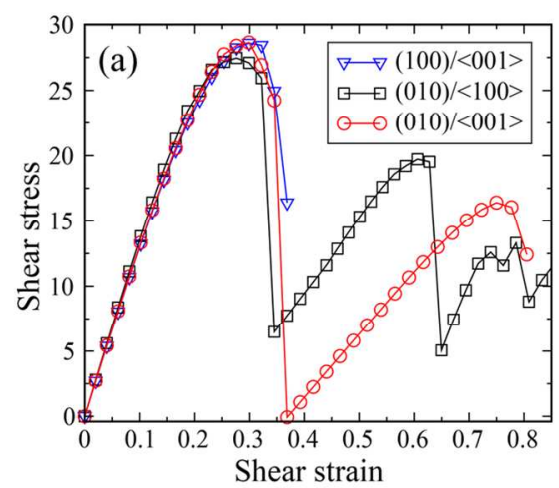

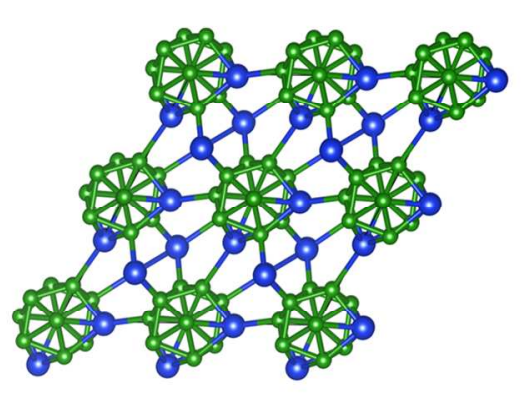

(b) Strain $=0.276$

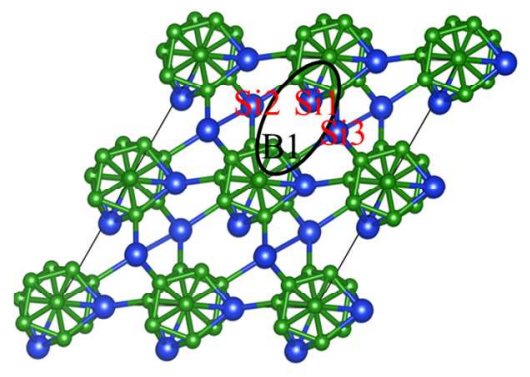

(c) Strain $=0.322$

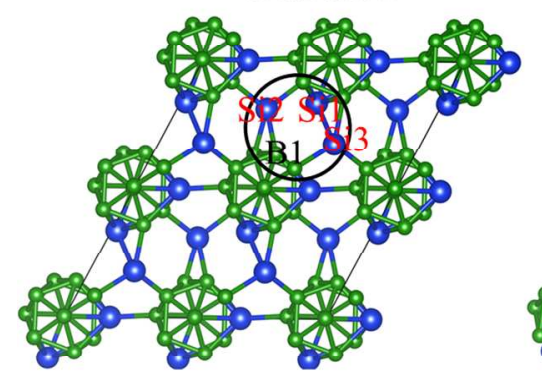

(d) Strain $=0.345$

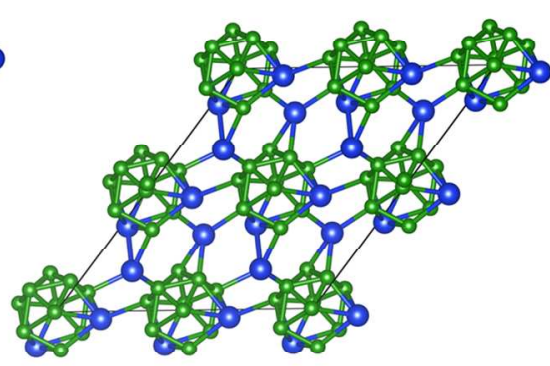

(e) $\operatorname{Strain}=0.628$

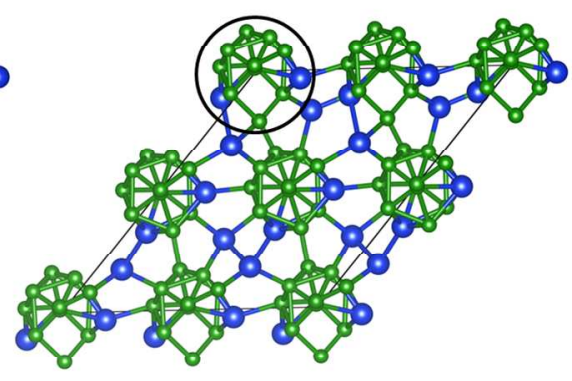

(f) Strain $=0.650$

Figure 3. The shear-stress-shear-strain relationship and structural changes for $m-\left(\mathrm{B}_{10} \mathrm{Si}_{2}\right) \mathrm{Si}_{2}$ shearing along (010)/<100>: (a) shear-stress-shear-strain relationship; (b) structure at 0.276 strain corresponding to maximum shear stress; (c) structure at 0.322 strain before the $1^{\text {st }}$ shear stress significant drop; (d) structure at 0.345 strain after stress release, no $\left(\mathrm{B}_{10} \mathrm{Si}_{2}\right)$ icosahedra are disintegrated; (e) structure at 0.628 strain before the failure; (f) structure at 0.650 strain where one layer of icosahedra is deconstructed. The key structural changes are shown in the solid ovals. The $\mathrm{B}$ and $\mathrm{Si}$ atoms are represented by green and blue balls, respectively. 


\section{Figure 4}

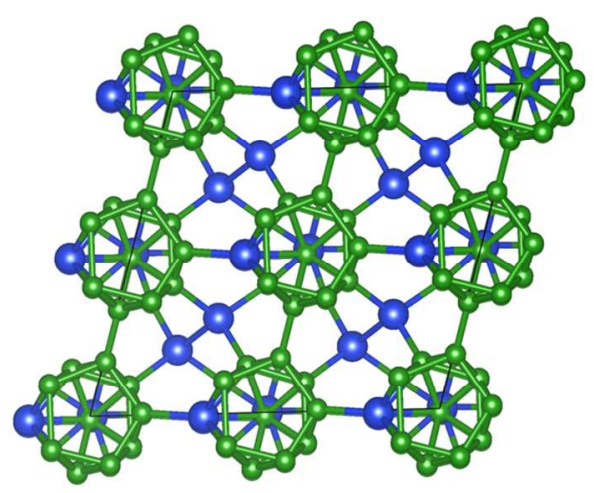

(a) Strain $=0.0$

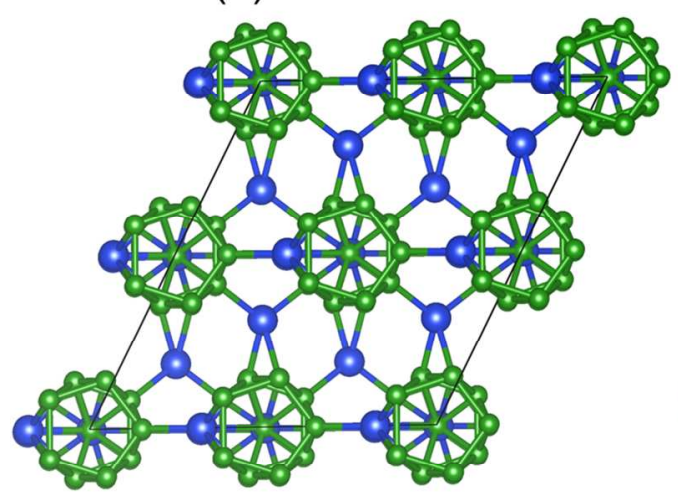

(c) Strain $=0.369$

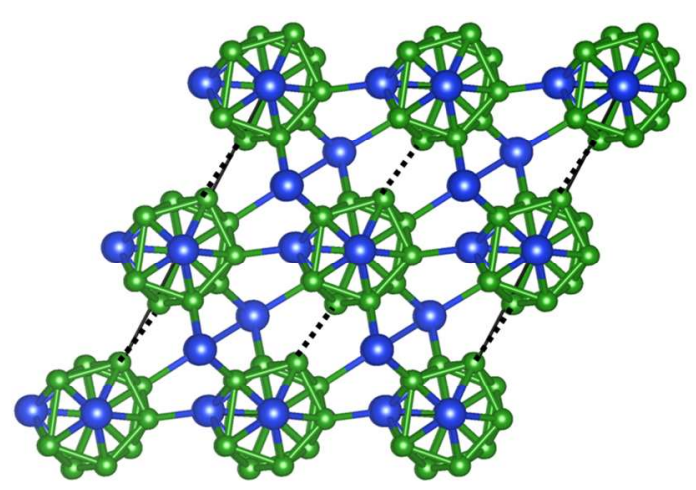

(b) Strain $=0.299$

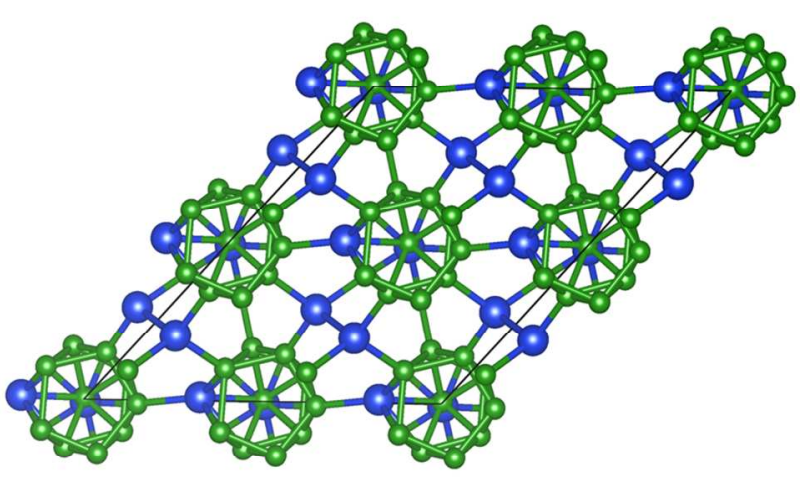

(d) Strain $=0.805$

Figure 4. The structural changes for $\mathrm{m}-\left(\mathrm{B}_{10} \mathrm{Si}_{2}\right) \mathrm{Si}_{2}$ shearing along $(010) /<001>$ slip system: (a) intact structure; (b) structure at 0.299 strain corresponding to the maximum shear stress; (c) structure at 0.369 strain where the $1^{\text {st }}$ shear stress significant drop, no $\left(\mathrm{B}_{10} \mathrm{Si}_{2}\right)$ icosahedra are disintegrated; (d) structure at 0.805 strain corresponding to the $2^{\text {nd }}$ shear stress release, no $\left(\mathrm{B}_{10} \mathrm{Si}_{2}\right)$ icosahedra are disintegrated. 
Figure 5

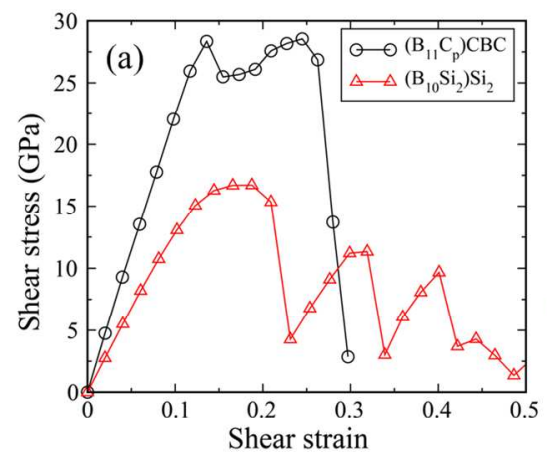

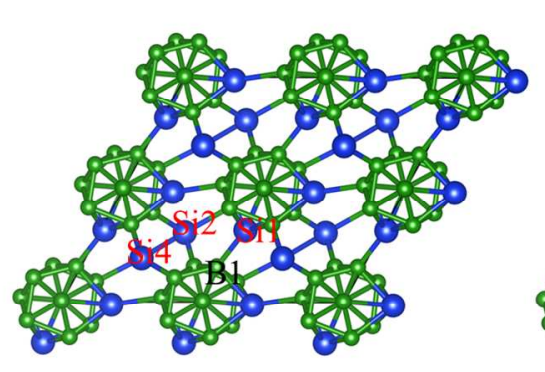

(b) Strain $=0.187$

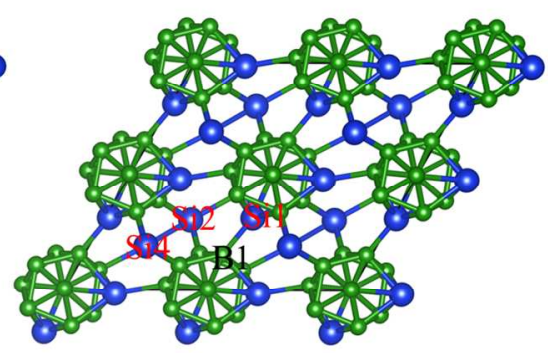

(c) Strain $=0.209$

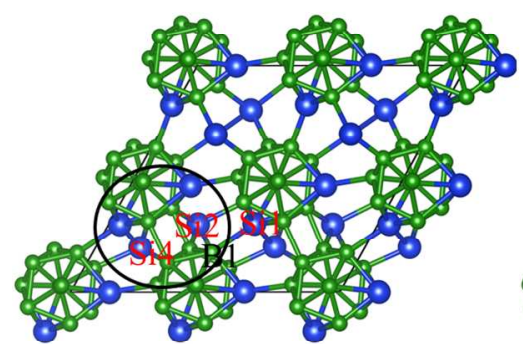

(d) Strain $=0.231$

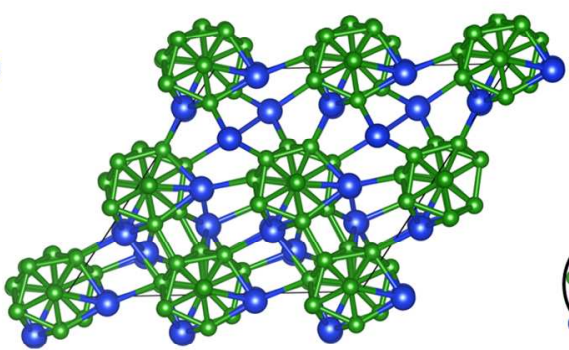

(e) Strain $=0.319$

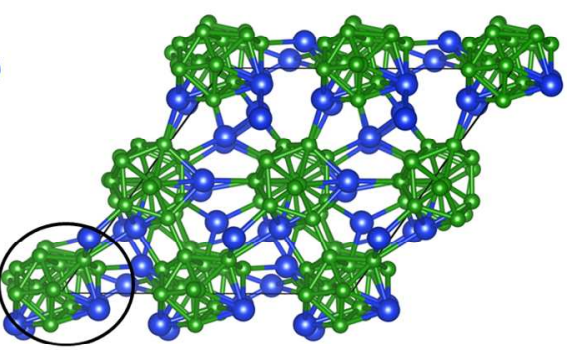

(f) Strain $=0.339$

Figure 5. The stress-strain relationships and structural changes for $\mathrm{m}-\left(\mathrm{B}_{10} \mathrm{Si}_{2}\right) \mathrm{Si}_{2}$ under biaxial shear deformation along the least shear slip system: (a) shear-stress-shear-strain relationship; (b) structure at 0.187 strain corresponding to the maximum shear stress; (c) structure at 0.209 strain before the $1^{\text {st }}$ significant stress drops; (d) structure at 0.231 strain where the stress is released by the slip of icosahedral clusters without fracturing them; (e) structure at 0.319 strain before failure; (f) structure at 0.339 after failure where one layer of icosahedral cluster are deconstructed. This simulation aimed at mimicking deformation under the indenter by imposing the relations $\sigma_{\mathrm{zz}}=\sigma_{\mathrm{zx}} \times \tan \Phi$ where $\sigma_{\mathrm{zz}}$ is the normal stress, $\sigma_{\mathrm{zx}}$ is the shear stress and $\Phi$ is the centerline-to-face angle of the Vickers indenter. The $\mathrm{B}$ and $\mathrm{Si}$ atoms are represented by green and blue balls, respectively. The key structural changes are shown in the solid ovals. 


1
2
3
4
5
6
7
8
9
10
11
12
13
14
15
16
17
18
19
20
21
22
23
24
25
26
27
28
29
30
31
32
33
34
35
36
37
38
39
40
59
50
50
49
50
51
52
53
44
54

TOC Graphic

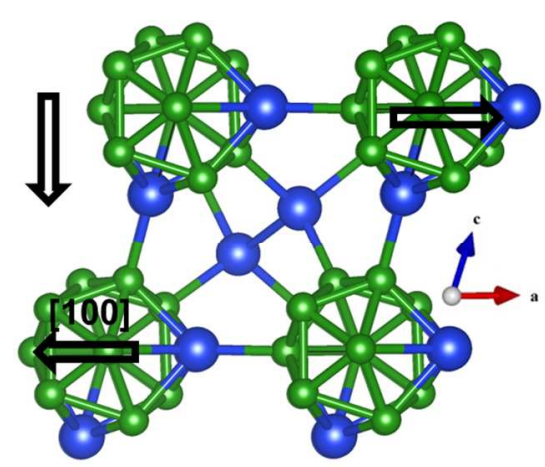

19

20

21

23

24

25

26

27

28

30

31

32

33

34

35

36

37

38

39

40

41

42

43

45

46

47

48

49

51

52

53

54

55

56

57

58

59 